\title{
EFFICIENCY OF RAW MATERIAL INVENTORIES IN IMPROVING SUPPLY CHAIN PERFORMANCE OF CV. FIVA FOOD
}

\author{
Artadi Nugraha*), Sukardi**), and Amzul Rifin $\left.{ }^{* * *}\right)$ \\ *) School of Business, Bogor Agricultural University \\ Jl. Raya Pajajaran, Bogor 16151 \\ ${ }^{* *}$ Department of Agroindustrial Technology, Faculty of Agricultural Engineering and Technology, \\ Bogor Agricultural University \\ PO BOX 220, Campus IPB Dramaga, Bogor 16602 \\ ${ }^{* * *}$ Department of Agribusiness, Faculty of Economics and Management, Bogor Agricultural University \\ Jl. Kamper, Wing 4 Level 5 Campus IPB Dramaga, Bogor 16680
}

\begin{abstract}
The production and number of processed food industries have slightly increased; as a result, the companies must compete to maximize their profits by conducting their efficient production process. CV. Fiva Food is one of the companies in the field of processed foods, especially in processed meat that has implemented supply chain management. It is necessary for the company to take measurements of its performance and efficiency for the entire supply chain such as procurement of raw materials. The purposes of this study were to analyze the performance of the company's supply chain and determine the most efficient method of procurement for its raw materials as well as and to provide recommendations for the company to improve its performance of entire supply chain. This study used SCOR in analyzing the performance of supply chain and EOQ and POQ method to be compared with the method that the company uses to determine which method of procurement for raw materials is the most efficient one. The result showed that based on the matrix, the company's performance is unfavorable when it was compared to the benchmark performance of inventory days of supply. In addition, this study showed that the POQ method produces the lowest total inventory cost with savings of Rp6.647.015 for raw materials of MDM whereas EOQ method produced the lowest total inventory cost with savings of Rp222.153,78 for raw materials of FQ85CL.
\end{abstract}

Keywords: performance suppy chain, SCOR, fiva food, EOQ, POQ

\begin{abstract}
ABSTRAK
Peningkatan produksi dan jumlah industri makanan olahan menyebabkan perusahaan saling bersaing dalam memaksimumkan keuntungan mereka dengan cara melakukan efisiensi terhadap proses produksinya. CV. Fiva Food merupakan salah satu perusahaan di bidang makanan olahan khususnya olahan daging yang telah lama menerapkan manajemen rantai pasok. Perusahaan perlu melakukan pengukuran terhadap kinerja dan efisiensi rantai pasoknya yaitu pengadaan bahan baku. Tujuan penelitian ini adalah menganalisis kinerja rantai pasok perusahaan dan menentukan metode pengadaan bahan baku yang paling efisien bagi perusahaan, serta memberikan rekomendasi bagi perusahaan dalam meningkatkan kinerja rantai pasoknya. Penelitian menggunakan metode SCOR untuk menganalisis kinerja rantai pasok, metode $E O Q$, dan metode $P O Q$ yang dibandingkan dengan metode perusahaan untuk mengetahui metode pengadaan bahan baku yang paling efisien. Hasil penelitian menunjukkan bahwa terdapat matriks kinerja perusahaan yang menunjukkan hasil yang kurang baik apabila dibandingkan dengan benchmark yaitu kinerja inventory days of supply (jumlah hari sediaan pasokan). Disamping itu, metode POQ menghasilkan total biaya sediaan terendah dengan penghematan sebesar Rp6.647.015 untuk bahan baku MDM, sedangkan untuk bahan baku FQ85CL metode EOQ menghasilkan total biaya sediaan terendah dengan penghematan sebesar Rp222.153,78.
\end{abstract}

Kata kunci: kinerja rantai pasok, SCOR, fiva food, EOQ, POQ

\footnotetext{
${ }^{1}$ Corresponding author:

Email: artadinugraha@gmail.com
} 


\section{INTRODUCTION}

Food and beverage industry is one of the strategic industries that give a major contribution to Gross Domestic Product (GDP) in the first quarter of 2014 with the amount of $23,56 \%$. The Central Bureau of Statistics (2014) states that there was growth in food production throughout the quarter 1 of 2014 by $9 \%$. This growth increased if compared to the production of food in the quarter 1 of 2013 by $0,3 \%$. Meat processing industry is one of the food industry subsectors that has experienced increased competition in terms of both quality and quantity. Agrina (2014) stated that the increase was a result of growth in meat consumption in Indonesia where the consumption of poultry meat in the country increased from $4,99 \mathrm{~kg} / \mathrm{capita} /$ year by 2010 to $6,28 \mathrm{~kg}, 6,97 \mathrm{~kg}, 8,08 \mathrm{~kg}$ from 2011 to 2013 successively, and it was predicted to reach $9,15 \mathrm{~kg} /$ capita/year in 2014. In addition, the consumption of beef in 2013 amounted to $2,1 \mathrm{~kg} /$ capita/year. One of the efforts made by the company in the face of the competition is to increase the performance of supply chain management so that it becomes effective and efficient. Supply chain management (SCM) is an integration of key business processes from an end user through an original supplier that provides products, services, and information that add value for customers and other stakeholders (Chan and Qi, 2003).

CV. Fiva Food is one of the food sub-sector companies engaged in the meat processing industry which has been registered as a member of the National Meat Processor Association (NAMPA) and has already obtained a halal certification issued by BPOM-MUI and has implemented the supply chain management. To measure the performance of its supply chain management, CV. Fiva Food requires a performance measurement system that can assists the company in evaluating its performance in achieving its target. One measurement model that can be used in measuring the performance of supply chain management is a model of Supply Chain Operations Reference (SCOR). Irfan, Xiaofei and Seng Chun (2008) explained that the supply chain management system business application process, sustainability, and practices can be obtained from SCOR. SCOR Model allows companies to communicate, compare and learn from their competitors both from the similar and different types of companies.

Chopra and Meindl (2007) state that the supply chain management performance is determined by several factors, namely, preparation, transportation, facilities and information. Fleisch and Tellkamp (2005) argue that there are several reasons why the supply record is inaccurate, and some of the reasons include mis-delivery of goods coming in and going out of the company, errors in transactions, and errors in goods placements. Lorentz (2008) mentions that the lack of quality supply of raw materials, especially in the processing of meat and milk, is a significant problem in the food processing industry. Khalid (2008) in his research suggests that the management of the supply in the manufacturing industry needs to gain attention and critical reviews in order to avoid interruption of the production process and improve operating performance. Rajeev (2008) states inaccuracy in the supply costs causes productivity loss, potential loss due to the inability to meet customer demand, and frustration which causes a direct impact on the company's financial strength and competitive advantage. Based on the results of these studies, it is known that one way of improving the company's supply chain performance is to conduct an efficient inventory process.

Total cost of supply is determined based on costs of order and storage. The data shown in the data of one of the main raw materials in CV. Fiva Food is mechanical debone meat (MDM) show that the total number of orders in a year made by the company reached 68 orders. In addition, the average amount of the rest of storage from the production process is also reasonably great i.e. 3,5 tons. Value of the excessive supply can cause excessive spending on the company, thus reducing the company's profit, while lack of supply can have an impact on the inhibition of the production process, thus reducing the sales performance which leads to the risk of losing consumers and customers.

Therefore, there should be an analysis on the company's raw material supply so that the preparation of the raw materials can be more efficient. In regards to the related to the issues presented, the objectives of the research were to analyze the performance of supply chain management currently carried out by the company, to identify the most efficient method of procurement of raw materials conducted by the company i.e. EOQ method, POQ method and company method, and to provide alternative solutions for controlling the supply of raw materials efficiently. This study was limited to the scope of the data of order, inventory and raw material supply used starting from October 2013 to September 2014, and the observed raw materials were limited to those belonging to class $\mathrm{A}$ in the $\mathrm{ABC}$ classification and measurement of supply chain performance using SCOR approach focused on the level 1 matrix. 


\section{METHOD}

The primary data were collected from the interviews, direct observations and questionnaires distributed to the general manager, production and operation managers, distributors, and agents of CV. Fiva Food. Technique sampling was done by purposive sampling on the basis that the respondents have the experience, expertise and competence so that they were considered to be the representatives in responding the questions in the questionnaire. Interviews were conducted to obtain information and data related to supply chains in the company, among others, the amount of production and sales, amount of supply and distribution as well as partnerships between suppliers and distributors.

This technique was supported by the filling out the questionnaire and field survey to obtain a picture of the implementation of the company supply chain. Direct observations were carried out to determine the condition of the company including mechanisms of raw material procurement, production process flow, and product distribution mechanism. Literature studies provide theoretical information as the reference to achieve the expected goals. The secondary data collection was based on company reports, data preparation and use of raw materials starting from October 2013 to September 2014. The raw material data used in this research were the primary raw materials commonly used in the production process by the company, namely, mechanical debone meat (MDM) and fore quarter chemical lean (FQ85CL).

\section{Matrix Calculation of SCOR Performance}

A number of frameworks and models for performance measurement have been developed since 1980s (Bititci et al., 2000). Gomes et al. (2004) suggested that performance measurement evolved through two stages where the first phase began in the late $1880 \mathrm{~s}$, and the second phase began in the late 1980s. According to Melynk et al. (2004), a performance measurement system usually contains: i) individual matrixes; ii) a series of performance matrixes, and iii) a comprehensive performance measurement system. Cagnazzo et al. (2010) classifies the basic grouping of performance measurement systems into five models, namely: (1) Balanced Models, (2) Quality Models, (3) Qestionnairebased Models, (4) Hierarchical Models and (5) Support Models. There are 12 matrix performances as parts of the SCOR model to measure the performance process which is classified into: (i) Delivery reliability; (ii) flexybility and responsiveness; (iii) Costs; and (iv) Asset (Huan et al. 2004). The parameters measured based on attributes as the performance matrix are as follows:

\section{a. Perfect Order Fulfillment (POF)}

POF is the percentage of orders delivered completely and on time in accordance with customer demand and the delivered goods have no quality problem. The following is the formula to determine the value of POF:

$$
\text { POF }=\frac{\text { Total Orders Perfect }}{\text { Total Orders }} \times 100 \%
$$

\section{b. Order Fulfillment Cycle Time (OFCT)}

OFC is the number of days (time) required from the day when the order is received to the day when the product is received by customers. In determining the OFCT value, the average number of days required in the delivery of products to customers can be measured. The following is the formula to determine the value of OFCT:

$$
\begin{aligned}
& \text { The actual number of cycle time for } \\
& \text { all orders sent (days) }
\end{aligned}
$$

\section{Analysis of $\mathrm{ABC}$ Classification}

According to Gaspersz (1998), there are several stages in the analysis according to the $\mathrm{ABC}$ classification: 1). Determining the volume per time period inventory for the classified materials 2). Calculating the total inventory cost per time period by multiplying the volume of inventory at a cost per unit. 3). Calculating the total value of the aggregate inventory of all ingredients. 4). Registering these materials in the ranking of the percentage of the total inventory cost from the largest to smallest amount. 5). Classifying these materials into groups of A, B or C. The use of software POM-QM two versions can also be used to help classify the raw materials into classes of $\mathrm{A}, \mathrm{B}$ and $\mathrm{C}$. The $\mathrm{ABC}$ analysis with software POM-QM can be used by: 1). Clicking and selecting Inventory Module, File, New and ABC Analysis; 2). Entering a title in the Title column and then click OK; 3). Filling in the data in accordance with the data of raw materials owned; and 4). Clicking Solve to see the results of the calculation. 


\section{Raw Material Procurement Analysis}

Data processing for controlling the supply of raw materials was conducted by using EOQ and POQ methods. Maisuriya and Bhatwala (2013) used EOQ method in their research as quantity controller and total cost per unit in which the main objective of the study was to produce a model that could maximize profits. Before performing the analysis, it is necessary to firstly estimate the preparation cost consisting of order and storage costs by collecting and classifying the components of the storage and order costs in order to get the total cost of raw material supply.

1. The formula to calculate order costs is as follows:

$$
\mathrm{Oc}=\mathrm{SD} / \mathrm{Q}
$$

\section{Description:}

$\mathrm{Oc}=$ Order cost of raw materials per period

$\mathrm{S}=$ Order cost of raw materials per order in rupiah

$\mathrm{D}=$ Usage or demand estimated per time period

$\mathrm{Q}=$ Number of ordersin units

2. The formula to calculate storage cost is as follows:

$$
\mathrm{Ch}=\mathrm{HQ} / 2
$$

\section{Description :}

Ch $=$ Total storage cost of raw materials per period

$\mathrm{Q} / 2$ = Average level of inventory

$\mathrm{H}=$ Storage cost per unit per period in rupiah

Total cost of preparation is as follows:

$$
\mathrm{TC}=\mathrm{Oc}+\mathrm{Ch}
$$

3. The formula to calculate inventory control of EOQ method is as follows:

a. Determination of Optimum Quantity

$$
\mathrm{EOI}=\frac{E O Q}{R}
$$

b. ROP determination without safety preparations

$$
\mathrm{ROP}=\mathrm{d} \times \mathrm{L}
$$

4. The formula to calculate inventory control of POQ method is as follows:

a. Interval order determination

$$
\mathrm{EOQ}=\sqrt{\frac{2 D S}{H}}
$$

b. Inventory target determination

$$
\mathrm{R}_{\mathrm{poq}}=\mathrm{d}_{\mathrm{t}+\mathrm{L}}+\mathrm{Z} \alpha \delta_{\mathrm{dtL}}
$$

Description:

$$
\begin{aligned}
& \text { D : Demand per period } \\
& \mathrm{H} \text { : Storage Cost } \\
& \text { L : Lead Time } \\
& \mathrm{Z} \alpha \text { : Safety Factor } \\
& \mathrm{S} \text { : Order Cost } \\
& \text { d : Daily demand } \\
& \mathrm{R} \text { : Average demand } \\
& \delta \mathrm{d} \quad: \quad \text { Standard deviation of demand }
\end{aligned}
$$

\section{RESULTS}

\section{Supply Chain Model of CV. Fiva Food}

CV. Fiva Food, in running its production operations (Figure 1), implements supply chain involving various stages from the supplier to the customer chain. The supply chain line is the order process line from raw materials to finished goods. In meeting the needs of its main raw materials in the production process of MDM and FQ85CL, it requires multiple suppliers. This is because the company cannot produce its own raw materials, and resources are limited, and it implements its stock production system of make to stock.

\section{Performance Measurement of Supply Chain System}

Tangen (2004) argues that performance is defined as the efficiency and effectiveness of an action. There are five performance attributes that are used in supply chain performance measurement using the SCOR method including supply chains of reliability, responsiveness, flexibility, costs, and assets. Each performance attribute has its own measurement method i.e. perfect order fulfillment for the reliability performance attribute, order fulfillment cycle time for the responsiveness performance attribute of the supply chain, flexibility of each supplier for the flexibility performance attribute of supply chain, inventory cost for the performance 
attribute of supply chain cost as well as cash to cash cycle and inventory days of supply for performance attribute of supply chain assets.

The results of performance measurement of supply chain companies based on external and internal measurements using SCOR methods can be seen in Table 1. The measurement results showed that the value inventory days of supply for MDM raw materials is 67 days and above the average benchmark value. Nevertheless, the value is not equal or exceeds the best benchmark value in its class that is 55 days, whereas for FQ85CL raw materials, the value of inventory days of supply is 88 days in which the value is worse when compared with the target of an average benchmark in its class that is 84 days. These results indicate that there are excessive inventories for FQ85CL raw materials. These excessive raw materials resulted in rising storage costs incurred by the company so that it reduced its profits earned. Waller, Nachtmann, and Hunter (2006) show that the fate of a company depends on its ability to manageits inventories. The effectiveness of supply chain management has various advantages including an increase in customer value, increased profitability, reduced cycle time, better average level of inventories and better product designs (William et al. 2007).

\section{Analysis of $\mathrm{ABC}$ Classification}

$\mathrm{ABC}$ classification analysis is an analytical tool that is used for companies to classify supply based on their level of importance. The product cost is the deciding factor used in the classification of the ABC analysis. The product cost is obtained by multiplying the amount of demand for raw materials at a price per unit. The ABC analysis result using POM-QM software showed that there are two raw materials with the highest inventory value with the cumulative percentage of $67,36 \%$ i.e. fore quarter (FQ85CL) $(54,251 \%)$ and mechanical deboned meat (MDM) $(13,111 \%)$ with the percentage of usage included in class A.

\section{Analysis of Raw Material Supply}

Order cost is a fee that is required each time the supply is made by the company. Storage cost is a cost that must be incurred by the company in the process of storage of raw materials. In its main procurement of raw material i.e. MDM and FQ85CL, the company places an order in accordance with the number of orders required, in which the quantity of MDM raw materials supply is as much as $2.405 \mathrm{~kg}$ for one time order and that of FQ85CL raw materials is as much as $2.047 \mathrm{~kg}$ for onetime order. By the quantity of the order, in one period the company places 68 times and 39 times of orders for MDM raw materials and $\mathrm{FQ85CL}$ raw materials respectively (Table 2).

Calculation of inventory using EOQ method was analyzed using POM-QM software for windows second version (Production and Operations Management, Quantitive Methods). The optimal quantity of raw materials MDM is as much as $9.252 \mathrm{~kg}$, while the quantity of optimal order for FQ85CL raw materials is as much as $1.126 \mathrm{~kg}$. By knowing the optimal quantity, the number of estimated orders can be calculated by dividing the usage value of $\mathrm{D}$ and optimum $\mathrm{Q}$. The calculations showed that the number of orders for MDM iraw materials is as much as 18 orders per year.

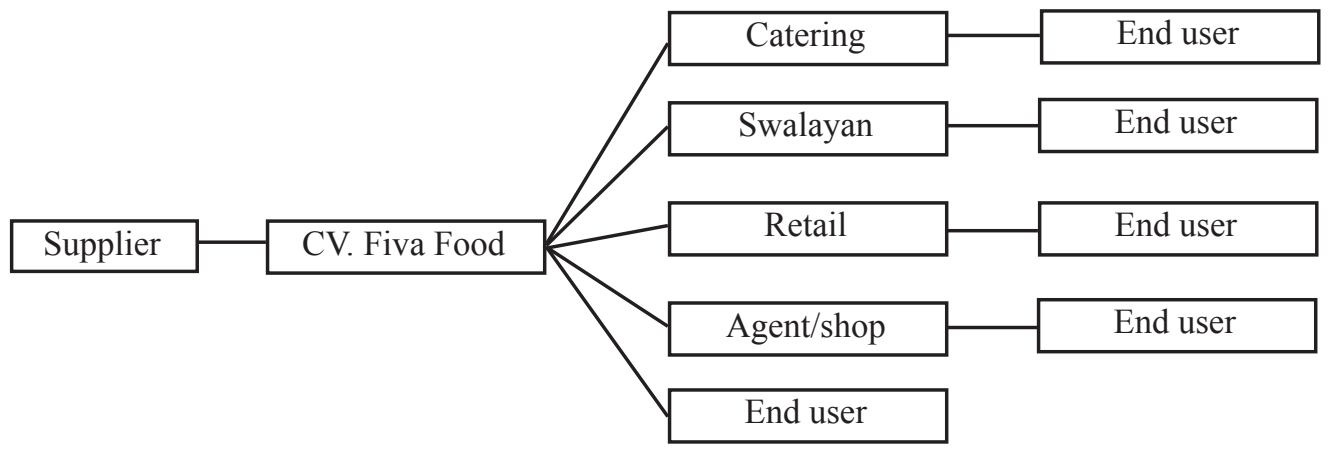

Picture 1. Supply chain model of CV. Fiva Food 
Table 1. Matrix card of SCOR level 1 in CV. Fiva Food

\begin{tabular}{|c|c|c|c|c|c|}
\hline Performance attribute & \multicolumn{2}{|c|}{ Level 1 matrix } & Actual (a) & Best in class & Average \\
\hline Reliability & \multicolumn{2}{|l|}{ Perfect order fulfillment } & $90,1 \%$ & $92,4 \%$ & $65,7 \%$ \\
\hline Responsiveness & \multicolumn{2}{|l|}{ Order fulfillment cycle } & 4 days & 1,8 & 4 \\
\hline \multirow[t]{3}{*}{ Flexibility } & \multirow[t]{3}{*}{ Flexibility of supply chain } & MDM Suppliers & $99 \%$ & $99 \%$ & $\mathrm{~N} / \mathrm{A}$ \\
\hline & & FQ85CL & $99 \%$ & $99 \%$ & N/A \\
\hline & & Distribution Channel & $99 \%$ & $99 \%$ & N/A \\
\hline \multirow[t]{2}{*}{ Cost } & \multirow[t]{2}{*}{ Inventory Cost } & MDM & Rp2.384.201.105 & $\mathrm{N} / \mathrm{A}$ & N/A \\
\hline & & FQ85CL & Rp4.790.987.669 & $\mathrm{N} / \mathrm{A}$ & N/A \\
\hline \multirow[t]{4}{*}{ Assets } & \multirow[t]{2}{*}{ Inventory Days of Supply } & MDM & 67 days & \multirow{2}{*}{55 days } & \multirow{2}{*}{84 days } \\
\hline & & FQ85CL & 88 days & & \\
\hline & \multirow[t]{2}{*}{ Cash to Cash Cycle } & MDM & 67 days & \multirow{2}{*}{35,6 days } & \multirow{2}{*}{99,4 days } \\
\hline & & FQ85CL & 72 days & & \\
\hline
\end{tabular}

Description: N/A = not applicable

Sources:

1. (a) The processed result at Fiva Food

2. (b) and (c) supply chain council, as quoted by Sidarto (2008), Purnamasari (2011)

Table 2. Companies method of raw material supply

\begin{tabular}{lcc}
\hline \multicolumn{1}{c}{ Variables } & MDM & FQ85CL \\
\hline Usage (D) $(\mathrm{Kg})$ & 163.534 & 79.826 \\
Order cost $(\mathrm{S})$ & $\mathrm{Rp} 178.500$ & $\mathrm{Rp} 8.500$ \\
Storage cost $(\mathrm{H})$ & $\mathrm{Rp} 682$ & $\mathrm{Rp} 1.071$ \\
Order quantity $(\mathrm{Kg})$ & 2.405 & 2.047 \\
Total order & 68 & 39 \\
\hline
\end{tabular}

As many as 71 orders for FQ85CL raw materials are placed per year. Order quantity period method is a method that is performed at the fixed order interval and allows the size of orders size to vary according to the economic order interval obtained (Henmaidi and Heryseptemberiza, 2007). In determining the interval time of order or economic order interval, EOQ should be used as the basis. Economic order interval value can beobtained by dividing the EOQ with the monthly average requirement. EOQ value of MDM raw materials is $9.252 \mathrm{~kg}$, whereas the EOQ value for the raw materials of $\mathrm{FQ} 85 \mathrm{CL}$ is $1.126 \mathrm{~kg}$. Results of calculation of economic order interval (EOI) for MDM raw materials is 0,68 months with the interval of 15 days once the company places an order, while the value of $\mathrm{EOI}$ for $\mathrm{FQ} 85 \mathrm{Cl}$ raw materials is 0,17 month or one order for every week with an order interval of FQ85CL raw materials of four days. When compared with the number of orders that has been made by the company, EOQ method produces fewer orders for MDM raw materials, but it has a more frequent order for FQ85CL raw materials. The large number of orders in the period is due to the quantity of booked orders; in addition, it is also caused by the order and storage costs of raw materials. The less frequency of orders made by using EOQ and POQ methods is due to the quantity of orders made using both methods where the quantity is also much greater compared to that made by the company.

Table 3 shows that the optimal quantity in a single order for MDM raw materials using the EOQ method amounted to $9.252 \mathrm{~kg}$; on the other hand, the optimal quantity is $9.085 \mathrm{~kg}$ using the POQ method. The opposite is shown in FQ85CL raw materials, where the quantity of an order made using the EOQ and POQ methods is less when compared to the quantity of an order made by the company. Result of calculation of reorder point (ROP) shows that the company needs to do a reorder for MDM raw materials to the supplier when the inventory is as much as $1,887 \mathrm{~kg}$ and reorder for $\mathrm{FQ85CL}$ raw materials when the inventory is as much as $921 \mathrm{~kg}$.

\section{Comparison of Inventory Total Cost among the Three Methods}

Total cost of inventory is the result of the sum of the order, storage and product cost. The results shown in Table 4 show that the total storage for MDM raw materials using POQ method generates a total cost of inventory of Rp2.377.553.985 and provides inventory cost saving of Rp6.647.015 or by $51,29 \%$ when compared with the results using the company method, whereas the use of POQ method on FQ85CL raw materials generates inventory total cost of Rp4.790.766.881 and provides inventory cost saving by Rp220.819 when compared with the results using the method performed 
by the company. Nevertheless, the EOQ and POQ methods on MDM raw materials when adjusted with a storage capacity of raw materials in the company cannot be applied because the storage capacity of the main raw materials (especially meat) only amounted to seven tons. If the company wants to apply POQ or EOQ methods, the company needs to add the storage capacity, and calculation of order and storage cost variables to determine the optimum order quantity have to be carried out. In addition, if the company cannot add storage capacity for its raw materials, the EOQ and POQ methods can still be applied but an adjustment with a storage capacity of its raw materials must be conducted.

Table 3. Comparison among the methods of POQ and EOQ and the company

\begin{tabular}{lcc}
\hline & MDM & FQ85CL \\
\hline (Q) Company (Kg) & 2.405 & 2.047 \\
Total Orders by the company method & 68 & 39 \\
$\left(Q^{*}\right)$ EOQ $(\mathrm{Kg})$ & 9.252 & 1.126 \\
Total Orders by the EOQ method & 18 & 71 \\
$\left(Q^{*}\right)$ EOQ with the adjustment with the warehouse capacity $(\mathrm{Kg})$ & 4.626 & - \\
Total Orders by the EOQ method with the adjustment with the warehouse capacity & 36 & - \\
(Q*) POQ (Kg) & 9.058 & 1.222 \\
Total Orders by the POQ method & 18 & 65 \\
(Q*) POQ with the adjustment with the warehouse capacity $(\mathrm{Kg})$ & 4.543 & - \\
Total Orders by the POQ method with the adjustment with the warehouse capacity & 36 & - \\
\hline
\end{tabular}

Table 4. Comparison of supply total costs among the three methods

\begin{tabular}{|c|c|c|}
\hline & $\begin{array}{c}\text { MDM } \\
\text { (Thousand Rp) }\end{array}$ & $\begin{array}{c}\text { FQ85CL } \\
\text { (Thousand Rp) }\end{array}$ \\
\hline Cost of company method order & $12.138,00$ & 331,50 \\
\hline Cost of company method storage & 820,10 & 1.096 .10 \\
\hline Cost of Products & $2.371 .243,00$ & $4.789 .560,00$ \\
\hline Total cost & 2.384.201,00 & $4.790 .987,70$ \\
\hline Cost of EOQ method order & $3.213,00$ & 602,73 \\
\hline Cost of EOQ method storage & $3.155,00$ & 602,78 \\
\hline Cost of Products & $2.371 .243,00$ & $4.789 .560,00$ \\
\hline Cost discrepancy of EOQ and company & $6.590,00$ & 222,15 \\
\hline Cost of EOQ method order by the adjustment with the warehouse capacity & $6.426,00$ & - \\
\hline Cost of EOQ method storage by the adjustment with the warehouse capacity & $1.577,50$ & - \\
\hline Cost of Products & $2.371 .243,00$ & - \\
\hline Cost discrepancy of the company method & $4.954,60$ & - \\
\hline Cost of POQ method order & $3.213,00$ & 552,50 \\
\hline Cost of POQ method storage & $3.097,98$ & 654,38 \\
\hline Cost of Products & $2.371 .243,00$ & $4.789 .560,00$ \\
\hline Total cost & $2.377 .553,98$ & $4.790 .766,88$ \\
\hline Discrepancy between POQ company & $6.647,02$ & 220,82 \\
\hline Cost of POQ method order by the adjustment with the warehouse capacity & $6.426,00$ & - \\
\hline Cost of POQ method storage by the adjustment with the warehouse capacity & $1.549,02$ & - \\
\hline Cost of Products & $2.371 .243,00$ & - \\
\hline Cost discrepancy of the company method & $4.982,98$ & - \\
\hline
\end{tabular}


Adjustment with a storage capacity of raw materials using EOQ method gives the total inventory cost savings on MDM raw materials is Rp4.954.639 or $38,23 \%$ with an order frequency as much as 36 times a year, whereas the use of POQ methods with adjustment capacity provides a total cost savings of preparation of Rp4.982.975 or 38,45\% and also booked for 36 times a year. The results of inventory control using the POQ and EOQ methods are consistent with the research conducted by Permana (2011) who analyzed alternative models of raw material procurement that can lower the total cost of the inventory to support the supply chain performance in PT Hadinata Brothers using the lot sizing method with four different techniques i.e. lot for lot, Economic Order Quantity (EOQ), Period Order Quantity (POQ), and Part Period Balancing (PPB).

The results showed that POQ technique produces the lowest total cost for inventory for plywood materials and generates savings up to $11,44 \%$, while LFL produces the lowest total cost of inventory for MDF raw materials and produces savings of $30 \%$ compared to that using the company method. These results are also consistent with the study conducted by Mathew (2013 where he also used EOQ method as a forecasting model for controlling the raw material inventories in retail companies, in which the forecasting model of inventory management previously made by the company caused inaccurate supply levels. The results showed that by controlling inventories using EOQ method can reduce the total storage cost as much as $20 \%$ compared with that using by the company method.

\section{Comparison of Number of End Stocks among the Three Methods}

Total purchase of MDM raw materials using EOQ method is greater compared with that using the company method. Based on the amount of purchase and average usage of MDM raw materials which amounted to 13,63 tons, the amount of end stocks reaches up to approximately 4,74 tons on average (Table 5).

This end stock value produces a larger quantity when compared to the method performed by the company. This final larger stock quantity is the result of the addition of the larger amount of purchase for each order made using EOQ method; however, the frequency of purchase is less than before i.e. 18 times. The addition of the mount of the end stock does not significantly affect the total cost of inventories undertaken by the company using EOQ method. This is because the cost of purchasing raw materials using EOQ method is also less than that made by the company in a year in which the purchases of raw materials reach 68 times.

Based on the usage amount of FQ85CL raw materials up to 79,83 tons in a year, the average monthly end stock amount of FQ85CL raw materials of 2,25 tons can be obtained, and this value of the end stock amount is greater compared that using the method performed by the company. Similar result was also obtained with the use of POQ method on MDM raw materials in which the average end stock value is greater when compared to that using the company methods, where the average end stock of each month reaches 5,45 tons. Different result was obtained from FQ85CL raw materials where the average end stock value gained is less compared with that of the company method and EOQ method that is 1,90 tonnes per month. These results indicate that POQ method can provide better cost saving and storage on FQ85CL raw materials.

Table 5. Comparison of supply total costs among the three methods

\begin{tabular}{lcccccc}
\hline & \multicolumn{2}{c}{ Company method } & \multicolumn{2}{c}{ EOQ method } & \multicolumn{2}{c}{ POQ method } \\
\hline & MDM & FQ85CL & MDM & FQ85CL & MDM & FQ85CL \\
\hline Baseline stock (Ton) & 2,00 & 2,90 & 2,00 & 2,90 & 2,00 & 2,90 \\
Total purchase (Ton) & 163,49 & 79,42 & 166,54 & 79,95 & 163,53 & 79,43 \\
Monthly average & 13,62 & 6,62 & 13,88 & 6,66 & 13,63 & 6,62 \\
Total inventory (Ton) & 163,53 & 79,83 & 163,53 & 79,83 & 163,53 & 79,83 \\
Monthly average & 13,63 & 6,65 & 13,63 & 6,65 & 13,63 & 6,65 \\
End stock (Ton) & 1,95 & 2,49 & 5,00 & 3,02 & 1,99 & 2,50 \\
Monthly stock average & 3,50 & 2,23 & 4,74 & 2,25 & 5,45 & 1,90 \\
\hline
\end{tabular}




\section{Managerial Implication}

Supply chain performance in CV. Fiva Food shows good results because the company has achieved several benchmark targets. A number of the performance targets needs to be improved by the company include the perfect order fulfillment order and inventory days of supply, and this will support the future performance of the company's order fulfillment order up to $100 \%$. One way that can be carried out by the company in improving the delivery performance is by the delivery timing; i.e. in the morning as well as the well-routed delivery (selection of smooth and good road conditions) which can help the company to reduce delays and maintain quality of the goods to be shipped.

In the process of procurement of raw materials, the company needs to conduct $\mathrm{ABC}$ analysis in advance to determine which raw materials are prioritized in controlling supplies. There are several methods that can be used by the company as an alternative to control raw materials including EOQ and POQ methods. Both methods can be considered to be an alternative method in the control of raw materials, for those have been proven to deliver cost-savings for supplies. The high order cost of MDM raw materials occurred because the supplier did not deliver the product; therefore, it is necessary for the company to seek alternative suppliers of MDM raw materials so that delivery costs can be reduced in terms of transportation. Alternative MDM raw material suppliers chosen by the company also needs to meet the criteria of quality and quantity required by the company. In addition, to further maximize the profit, the company needs to improve its marketing areas as well as to increase its production capacity.

\section{CONCLUSIONS AND RECOMMENDATIONS}

\section{Conclusions}

The performance of the company supply chain analyzed using SCOR method based on the performance attributes of the order complete fulfillment, order fulfillment cycle, supply chain flexibility as well as cash to cash cycle showed good results. The performance of the company's assets viewed through inventory days of supply shows that there are still raw materials which are less economical because their values exceed the benchmark; therefore, it is necessary to conduct analysis on raw material control.
The results of the comparison of the total supply cost among the methods of the company, EOQ and POQ showed that the POQ supply method produces the lowest total cost with savings of Rp6.647.015 for MDM raw materials. For FQ85CL raw materials, EOQ method produces the lowest total supply costs with savings of Rp222.153,78. The results of the analysis also showed that the optimum number of orders using the EOQ analysis for MDM raw materials is equals to $9.252 \mathrm{~kg}$ in which the adjustment to the company warehouse capacity is $4.626 \mathrm{~kg}$ while for the optimum quantity of FQ85CL raw materials is $1.126 \mathrm{~kg}$. The reorder point with EOQ method for MDM raw materials is $1.887 \mathrm{~kg}$ whereas for $\mathrm{FQ} 85 \mathrm{CL}$ raw materials it is 921 $\mathrm{kg}$.

To improve the performance of the supply chain in controlling raw materials, the company needs to keep continous and detailed records of raw materials because they are useful to identify the re-order point and optimum quantity order. Furthermore, alternative selections of MDM raw material suppliers are expected to meet the necessary criteria for the company to reduce order costs.

\section{Recommendations}

In controlling raw material supplies, the company can apply the $\mathrm{ABC}$ analysis to help determine which materials should be prioritized. In addition, there should be continuous and detailed data-recording to determine the re-ordered point and optimum quantity order. However, further researches can be conducted on the influence of the main raw material quality due to an increase in order quantity. Moreover, further research can also be conducted on marketing strategies of CV. Fiva Food products which are expected to increase sales and profit

\section{REFERENCES}

[AGRINA] Agribisnis Indonesia. 2014. Peluang Bisnis Manis Sosis. http://www.agrina-online. com/redesign2.php?rid=7\&aid=4914. [29 Maret 2015].

[BPS] Badan Pusat Statistik. 2014. Laju Pertumbuhan PDB Triwulanan Atas Dasar Harga Konstan 2001-2014.http://www.bps.go.id/tab_sub/ view.php?kat=2 \&tabel=1\&daftar $=1 \&$ id subyek $=11 \&$ notab $=23$. [1 September 2014].

Bititci US, Turner T. 2000. Dynamics of performance measurement systems.

International 
Journal of Operations and Production Management 20(6): 692-704. http://dx.doi. org/10.1108/01443570010321676.

Cagnazzo L, Taticchi P, Brun A. 2010. The role of performance measurement systems to support quality improvement initiatives at supply chain level. International Journal of Productivity and Performance Management 59(2):163-185. http://dx.doi.org/10.1108/17410401011014249

Chan F, Qi HJ. 2003. An innovative performance measurement method for supply chain management. Supply Chain Management: An International Journal 8(3):209-223.http:// dx.doi.org/10.1108/13598540310484618.

Chopra S, Meindl P. 2007. Supply Chain Management: Strategy, Planning, and Operation (3rd ed.). New Jersey: Pearson Education International.

Fleisch E, Tellkamp C. 2005. Inventory inaccuracy and supply chain performance: A simulation study of a retail supply chain. International Journal of Production Economics 95(3):373-385.http:// dx.doi.org/10.1016/j.ijpe.2004.02.003.

Gaspersz V. 1998. Production Planning and Inventory Control. Jakarta: Gramedia Pustaka Utama.

Gomes CF, Yasin MM., Lisboa JV. 2004. A literature review of manufacturing performance measures and measurement in an organizational context: a framework and direction for future research. Journal of Manufacturing Technology Management 5(6):511-530.http://dx.doi. org/10.1108/17410380410547906.

Henmaidi, Heryseptemberiza. 2007. Evaluasi dan penentuan kebijakan sediaan bahan baku kantong semen tipe pasted pada PT. Semen Padang. Jurnal Optimasi Sistem Industri 6(2): 75-86.

Huan SH, Sheoran SK, Wang G. 2004. A review and analysis of Supply Chain Operations Reference Model. Supply Chain Management: An International Journal 19(1):23-29. http://dx.doi. org/10.1108/13598540410517557

Irfan D, Xiaofei X, Seng Chun D. 2008. A SCOR reference model of the supply chain management system in an enterprise. The International Arab Journal of Information Technology 5(3):287295.

Khalid S. 2008. Trend forecasting for stability in supply chains. Journal of Business Research 61:1113-1124.http://dx.doi.org/10.1016/j. jbusres.2007.11.005.

Lorentz H. 2008. Production locations for the internationalizing food industry: case study from
Russia. British Food Journal 110(3):310-334. http://dx.doi.org/10.1108/00070700810858718.

Maisuriya AR, Bhathawala PH. 2013. A deterministic economic order quantity model with delays in payments and price discount offers. International Journal of Engineering Research and Applications 3(5):384-385.

Mathew A. 2013. Demand forecasting for economic order quantity in inventory management. International Journal of Scientific and Research Publications 3(10):2250-3153.

Melynk SA, Stewart DM, Siwank M. 2004. Metrics and performance measurement in operation management : Dealing with metric maze. Journal of Operation Management 22: 209-217.http:// dx.doi.org/10.1016/j.jom.2004.01.004

Permana HPP. 2011. Analisispengadaan bahan baku sebagai bagian dari internal supply chain management PT. Hadinata Brothers. [Tesis]. Sekolah Pascasarjana, Institut Pertanian Bogor. Bogor.

Purnamasari H. 2011. Peningkatan efisiensi manajemen rantai pasok melalui pengendalian sediaan filler dan bahan kemasan roti manis di PT. Nippon Indosari Corporindo. [Tesis]. Program Studi Magister Manajemen Agribisnis, IPB. Bogor.

Rajeev N. 2008. Inventory management in small and medium enterprises. Management Research News 31(9):659-669.http://dx.doi. org/10.1108/01409170810898554.

Sidarto. 2008. Konsep pengukuran kinerja supply chain management pada sistem manufactur dengan model performance of activity dan supply chain operations reference. Jurnal Teknologi 1(1):6877.

Tangen T. 2004. Performance measurement: from philosophy to practice. International Journal of Productivity and Performance Management 53(8):726-737.http://dx.doi.org/ 10.1108/17410400410569134.

Waller MA, Nachtmann H, Hunter J. 2006. Measuring the impact of inaccurate inventory information on a retail outlet. International Journal of Logistics Management 17(3):355-376.http:// dx.doi.org/10.1108/09574090610717527.

William JC, Germain RN, Birou L. 2007. Variance vs average: supply chain lead-time as a predictor of financial performance. Supply Chain Management: An International Journal 12(5):349-357. http://dx.doi.org/ 10.1108/13598540710776926. 